\title{
Líkamshreyfing 9 og 15 ára íslenskra barna í ljósi lýðheilsumarkmiða
}

Kristján Pór

Magnússon ${ }^{1}$

faraldsfræðingur

\section{Sigurbjörn Árni \\ Arngrímsson ${ }^{1}$} pjálfunarlífeðlisfræðingur

Pórarinn

Sveinsson ${ }^{2}$

lífeðlisfræðingur

Erlingur

Jóhannsson ${ }^{1}$

lífeðlisfræðingur

Lykilorð: hreyfing, börn, holdafar, hröðunarmælar.

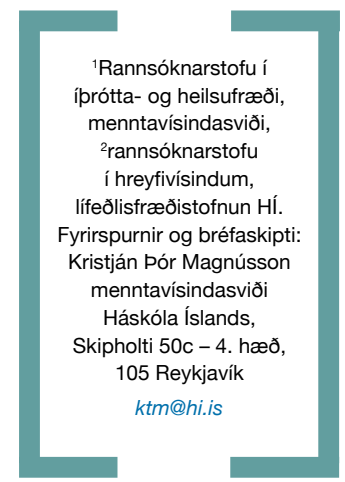

\section{Ágrip}

Tilgangur: Megintilgangur pessarar rannsóknar var að rannsaka í hvaða mæli 9 og 15 ára börn og unglingar á Íslandi uppfylltu nýlegar hreyfiráðleggingar Lýðheilsustöðvar.

Efniviður og aðferðir: Rannsóknin var gerð á tímabilinu september 2003 til janúar 2004 í 18 skólum á höfuðborgarsvæðinu og í péttbýliskjörnum og dreifbýli á Norðausturlandi sem valdir voru af handahófi. Öllum 9 ára (N=662) og 15 ára ( $\mathrm{N}=661)$ nemendum skólanna var boðin pátttaka. Helmingur hvors árgangs var valinn, einnig af handahófi, í hreyfihluta rannsóknarinnar og skiluðu 1769 ára og 16215 ára nothæfum gögnum. Pátttakendur voru hæðarog pyngdarmældir og pykkt húðfellinga mæld á fjórum stöðum. Ákefð og tímalengd hreyfingar var mæld með hröðunarmælum (ActiGraph ${ }^{\mathrm{TM}}$ ). Aðalútkomubreyta rannsóknarinnar, fjöldi mínúta yfir 3400 slög/mín á dag, miðaðist við neðri mörk hreyfingar af meðalerfiðri ákefð.

Niðurstöður: Samkvæmt hröðunarmælum uppfylltu 5\% úrtaks 9 ára barna hreyfiráðleggingar varðandi meðalerfiða og erfiða ákefð dag hvern, en tæp 9\% 15 ára unglinga. Aukin hreyfing af pessari ákefð var frekar tengd strákum en stelpum, pví að vera 15 ára frekar en 9 ára, að vera með minni pykkt húðfellinga en meiri, auk pess að búa á höfuðborgarsvæðinu frekar en í bæ eða strjálbýli á Norðausturlandi.

Ályktanir: Niðurstöðurnar benda til pess að íhlutunar sé pörf til pess að auka meðalerfiða og erfiða hreyfingu barna á skólaaldri. Mikilvægt er að rannsaka hvaða leiðir séu færar í peim efnum, meðal annars í samvinnu við heimili, skóla, ípróttahreyfinguna og sveitarfélög.

\section{Inngangur}

Jákvæð áhrif hreyfingar eru margvísleg, hvort sem litið er til áhrifa á líkamlega hreysti eða andlega líðan. ${ }^{1}$ Hreyfingarleysi er aftur á móti tengt ofpyngd og offitu, en pótt pau vandamál stafi af flóknu samspili margra pátta vitum við að hreyfing er einn af stóru forvarnarpáttunum sem komið geta í veg fyrir slíkt ástand. ${ }^{2}$ Раð eitt að almenningur tileinki sér að ganga reglulega á rösklegum hraða getur haft umtalsverð lýðheilsuleg áhrif og fækkað ýmsum langvarandi heilsufarsvandamálum. ${ }^{3}$ Af íslenskum rannsóknum má draga pær ályktanir að dagleg hreyfing barna hafi jafnvel aldrei verið jafn mikilvæg og nú sé pað sett í samhengi við pá fjölgun sem virðist hafa orðið í hópi peirra sem eru yfir kjörbyngd. ${ }^{4,5}$ Niðurstöður rannsóknar á próun ofpyngdar og offitu meðal sömu pátttakenda og pessi grein fjallar um (sjá grein frá 2006), ${ }^{4}$ gáfu eindregið til kynna að meirihluti peirra barna sem verða ung að árum of pung eða of feit, viðhalda pví líkamsástandi fram á unglingsár. Í pessu samhengi ber að kanna stöðu hreyfingar meðal íslenskra barna. Er hún almennt meiri eða minni en ráðleggingar kveða á um eða er nauðsynlegt að auka hana meðal barna á skólaaldri?

Mælingar á hreyfingu fólks eru af ýmsum toga og miklum upplýsingum hefur verið safnað með spurningalistum, pótt erfitt hafi reynst að sýna fram á nægjanlegan áreiðanleika og réttmæti slíkra lista. ${ }^{6}$ Síðasta áratug hafa hlutlægari mælingar á hreyfingu rutt sér til rúms og pá einkum notkun hröðunarmæla (e. accelerometers). Fjöldi greina ${ }^{7,8}$ hefur birst síðasta áratug sem tíunda niðurstöður slíkra mælinga á stöðu og próun hreyfingar og hreyfingarleysis meðal barna og fullorðinna en ekki hafa birst niðurstöður viðlíka mælinga á íslensku úrtaki fyrr en nú. ActiGraph ${ }^{\mathrm{TM}}$ hröðunarmælarnir hafa notið hvað mestra vinsælda, enda hefur verið sýnt fram á áreiðanleika peirra og réttmæti." ${ }_{10}$ Á hinn bóginn hafa vísindamenn ekki verið samstíga við útreikninga á ákefð hreyfingar, pað er meðalerfiðri og erfiðri hreyfingu (e. moderateto-vigorous physical activity), út frá mælieiningu hröðunarmælanna. ${ }^{11}$ Petta hefur valdið pví að mismunandi viðmið hafa verið notuð og par af leiðandi hafa mjög misvísandi niðurstöður litið dagsins ljós um hlutfall barna sem hreyfir sig í samræmi við viðteknar ráðleggingar um hreyfingu. ${ }^{12,13}$ 
Tafla I. Lýsandi tölfræði á einkennum úrtaks rannsóknarinnar.

\begin{tabular}{|c|c|c|c|c|c|c|}
\hline & \multicolumn{2}{|c|}{9 ára } & \multirow[b]{2}{*}{$\begin{array}{l}\text { 95\% ÖM fyrir } \\
\text { mun milli kynja }\end{array}$} & \multicolumn{2}{|c|}{15 ára } & \multirow[b]{2}{*}{$\begin{array}{l}\text { 95\% ÖM fyrir } \\
\text { mun milli kynja }\end{array}$} \\
\hline & $\begin{array}{l}\text { Stelpur }(\mathrm{n}=95) \\
\text { meðaltal }(\mathrm{SD})^{\star} / \\
\text { miðgildi }(\mathrm{QD})\end{array}$ & $\begin{array}{c}\text { Strákar }(\mathrm{n}=81) \\
\text { meðaltal } \mathrm{SD} / \\
\text { miðgildi }(\mathrm{QD})\end{array}$ & & $\begin{array}{c}\text { Stelpur }(\mathrm{n}=72) \\
\text { meðaltal }(\mathrm{SD})^{\star} / \\
\text { miðgildi }(\mathrm{QD})\end{array}$ & $\begin{array}{c}\text { Strákar }(\mathrm{n}=90) \\
\text { meðaltal }(\mathrm{SD})^{\star} / \\
\text { miðgildi }(\mathrm{QD})\end{array}$ & \\
\hline Aldur (ár) & $9,4(0,3)^{\star}$ & $9,4(0,3)^{*}$ & $(-0,1 ; 0,08)$ & $15,3(0,3)^{\star}$ & $15,3(0,3)^{\star}$ & $(-0,1 ; 0,1)$ \\
\hline Нæð (cm) & $138,0(7,0)^{\star}$ & $138,9(6,0)^{\star}$ & $(-0,8 ; 3,1)$ & $165,1(6,0)^{\star}$ & $176,5(7,0)^{\star}$ & $(9,1 ; 13,4)$ \\
\hline Pyngd (kg) & $32,1(4,0)$ & $32,2(4,6)$ & $(-1,2 ; 2,4)$ & $58,0(6,4)$ & $63,5(6,3)$ & $(4,8 ; 11,1)$ \\
\hline Húőpykkt $(\mathrm{mm})^{\dagger}$ & $40,0(12,9)$ & $31,0(11,9)$ & $(3,0 ; 12,0)$ & $58,8(16,2)$ & $37,8(17,0)$ & $(13,5 ; 25,0)$ \\
\hline BMI (byngd/hæð²) & $17,1(1,3)$ & $16,7(1,7)$ & $(-0,6 ; 0,7)$ & $20,4(1,7)$ & $20,7(2,2)$ & $(-0,8 ; 0,9)$ \\
\hline Hlutfall of pungra/of feitra ${ }^{\ddagger}$ & $14,7 \%$ & $22,2 \%$ & - & $15,3 \%$ & $22,2 \%$ & - \\
\hline Slög/mín alla daga & $580,9(101,0)$ & $683,8(115,7)$ & $(48,4 ; 152,6)$ & $449,6(79,9)$ & $571,4(108,4)$ & $(56,4 ; 175,6)$ \\
\hline Slög/mín virka daga & $610,0(94,4)$ & $728,1(123,4)$ & $(48,4 ; 152,6)$ & $473,9(87,0)$ & $594,8(126,0)$ & $(59,3 ; 178,1)$ \\
\hline Slög/mín um helgar & $490,7(122,9)$ & $584,5(139,3)$ & $(14,3 ; 139,2)$ & $359,9(96,3)$ & $476,0(165,8)$ & $(56,4 ; 175,8)$ \\
\hline Hreyfing yfir 3400 slög/mín (mín/dag) & $20,0(8,2)$ & $30,2(12,6)$ & $(4,4 ; 13,4)$ & $22,5(7,8)$ & $36,1(13.7)$ & $(8,3 ; 18,4)$ \\
\hline Meðalfjöldi lota yfir 3400 slög/mín/dag & $12,2(4,1)$ & $17,2(5,6)$ & $(2,3 ; 6,9)$ & $9,7(2,6)$ & $13,2(3,7)$ & $(1,9 ; 5,2)$ \\
\hline Meðallengd lota yfir 3400 slög/mín/dag & $1,6(0,2)$ & $1,7(0,2)$ & $(0,02 ; 0,2)$ & $2,4(0,4)$ & $2,8(0,6)$ & $(0,1 ; 0,6)$ \\
\hline \multicolumn{7}{|c|}{ 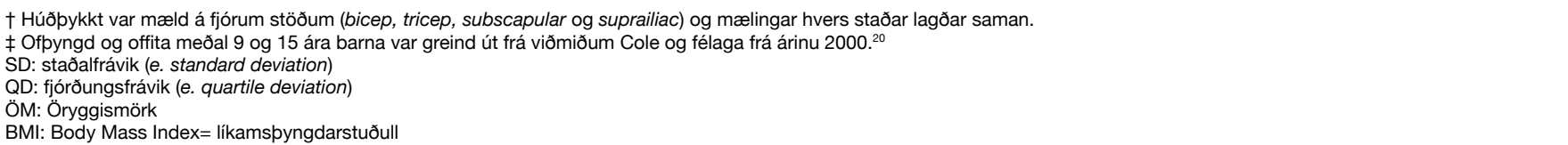 } \\
\hline
\end{tabular}

Árið 2008 gaf Lýðheilsustöð út ráðleggingar um hversu mikið almenningur skuli hreyfa sig að jafnaði svo heilsubót hljótist af. ${ }^{14}$ Ráðleggingarnar byggjast á erlendum rannsóknum og svipuðum viðmiðum hinna Norðurlandanna. Við mat á ákefð hreyfingar í pessari rannsókn var stuðst við viðmið Guinhouya og félaga á neðri mörkum meðalerfiðrar hreyfingar sem miðast við 3400 slög/mín. ${ }^{15}$ Samræmist petta viðmið niðurstöðum annarra rannsókna sem styðjast allar við neðri mörk sem ekki eru lægri en 3000 slög/mín. ${ }^{12,16,17}$

Tilgangur pessarar pversniðsrannsóknar var: a) að rannsaka í hvaða mæli 9 og 15 ára gömul börn og unglingar uppfylltu nýlegar ráðleggingar um æskilega hreyfingu og ákefð hennar samkvæmt niðurstöðum viðurkenndra hlutlægra mælinga (hröðunarmælaslög), og b) að kanna hvort pættir eins og búseta, aldur, kyn og holdafar tengdust meðalerfiðri og erfiðri hreyfingu.

\section{Efniviður og að̆ferठ̈ir}

Rannsóknarsnið og val á pátttakendum

Niðurstöðurnar í pessari grein eru hluti af rannsókninni Lífsstíll 9 og 15 ára Íslendinga. Tengdum niðurstöðum er varða petta úrtak íslenskra barna hafa verið gerð skil áður. ${ }^{4,18}$ Gagna var aflað að fyrirmynd evrópskrar rannsóknar, European Youth Heart Study (EYHS) ${ }^{19}$ sem ætlað var að kanna áhættupætti hjartasjúkdóma meðal barna og unglinga. Rannsóknin var gerð á tímabilinu september 2003 til janúar 2004 í
18 skólum á höfuðborgarsvæðinu (Reykjavík, Kópavogi, Hafnarfirði), í péttbýliskjörnum (Akureyri, Egilsstöðum, Húsavík) og dreifbýli (Eyjafirði, Pingeyjarsýslu, Fljótsdalshéraði) á Norðausturlandi sem valdir voru af handahófi. Úrtak skólanna var valið pannig að pað endurspeglaði sem best hlutfallslegan fjölda barna alls pýðisins miðað við tegund búsetu. Öllum 9 ára $(\mathrm{N}=662)$ og 15 ára $(\mathrm{N}=661)$ nemendum skólanna 18 var boðin pátttaka í rannsókninni. Helmingur peirra sem páðu að taka pátt $(n=660)$ var handahófsvalinn til að undirgangast hreyfihluta rannsóknarinnar og skiluðu 338 einstaklingar nothæfum gögnum (176 9 ára og 16215 ára). Upplýsingar um einkenni úrtaksins og samanburð á kynjum eftir aldri eru í töflu I. Um 46\% pátttakenda í hreyfihluta rannsóknarinnar komu úr skólum á höfuðborgarsvæðinu, 41\% frá péttbýliskjörnum á Norðausturlandi og 13\% pátttakenda bjuggu í dreifbýli. Rannsóknarleyfi var veitt af Vísindasiðanefnd (VSNa2003060014/03-12/BH/--).

\section{Holdafarsmælingar}

Pátttakendur rannsóknarinnar voru hæðar- og pyngdarmældir á léttum nærfatnaði og samkvæmt hefðbundnum aðferðum með nákvæmni uppá 0,1 sm (hæð) og 0,1 kg (pyngd). Pykkt húðfellinga var mæld með húðfellingamæli á fjórum stöðum á líkamanum: aftan á upphandlegg (e. tricep), framan á upphandlegg (e. bicep), neðan herðablaðs (e. subscapular) og ofan mjaðmakambs 
(e. suprailiac). Gerðar voru prjár mælingar á hverjum stað og meðaltal hvers staðar fundið. Summa af pykkt húðfellinga hvers einstaklings var fengin með pví að leggja saman meðaltöl staðanna fjögurra. Sömu tveir aðilarnir gerðu allar húðpykktarmælingarnar. Líkamspyngdarstuðull (Body mass index - BMI) var reiknaður $\left(\mathrm{kg} / \mathrm{m}^{2}\right)$ og borinn saman við viðmiðunargildi um ofpyngd og offitu..$^{20}$

\section{Mælingar á hreyfingu}

Hreyfing eða virkni helmings peirra sem tóku pátt (valið af handahófi) var mæld með ActiGraph ${ }^{\mathrm{TM}}$ 7124 hröðunarmælum. Mælarnir eru litlir kubbar á stærð við eldspýtnastokk sem festir voru á pátttakendur með teygju um mittið pannig að peir sætu við hægri mjöðm. Ætlast var til að mælirinn væri á viðkomandi pann tíma sem hann/hún væri vakandi (nema ef farið væri í sund/bað) í sex daga frá og með peim degi sem hann var settur á. ActiGraph ${ }^{\mathrm{TM}}$ hröðunarmælirinn mælir meðaltalsákefð hreyfingar í einu plani (e. uni-axial) yfir einnar mínútu tímabil en upplýsingarnar eru vistaðar sem slög í minni mælisins. Pannig voru vistuð meðaltalsslög hverrar mínútu hvers pátttakanda yfir sex daga í hverjum skóla. Viðmið um úrvinnslu gagna úr hröðunarmælunum, til að mynda um hversu lengi mælarnir skyldu hafðir á og hve margar klukkustundir peir pyrftu að vera í notkun hvern dag, voru fengin frá EYHS til að tryggja samanburðarhæfni niðurstaðnanna. ${ }^{19}$ Eingöngu var notast við gögn úr mælum sem höfðu mælt hreyfingu í minnst einn helgidag og tvo virka daga, minnst 10 klukkustundir hvern dag. Mælirinn var talinn óvirkur (ekki í notkun) ef núll slög á mínútu voru í minni mælisins í samfelldar 10 mínútur eða meira og var sá tími pví dreginn frá heildartímanum. Myndir 1a og 1b sýna dæmi um niðurstöður tveggja einstaklinga sem hreyfðu sig mismikið yfir rannsóknartímabilið.

Aðalútkomubreyta rannsóknarinnar er fjöldi mínúta yfir 3400 slög/mín á dag sem er skilgreiningin á neðri mörkum meðalerfiðrar hreyfingar. Áður hefur verið lagt til að 3400 slög/mín séu pau viðmið sem notast skuli við sem neðri mörk pessarar ákefðar. ${ }^{15}$ Sá slagafjöldi á mínútu er mitt á milli tveggja viðmiða sem hvað mest hafa verið notuð í nýlegum rannsóknum, pað er 3200 slög/ mín ${ }^{17}$ og 3600 slög/mín. ${ }^{21}$

\section{Tölfræði}

Við mat á normaldreifingu breytanna var stuðst við einföld tíðnistöplarit (e. histogram), niðurstöður Anderson-Darling-prófs, Shapiro-Wilkins-prófs, og skekkju- og risgilda (e. skewness $\mathcal{E}$ kurtosis) minni en 2. Við samanburð milli kynja eftir aldri

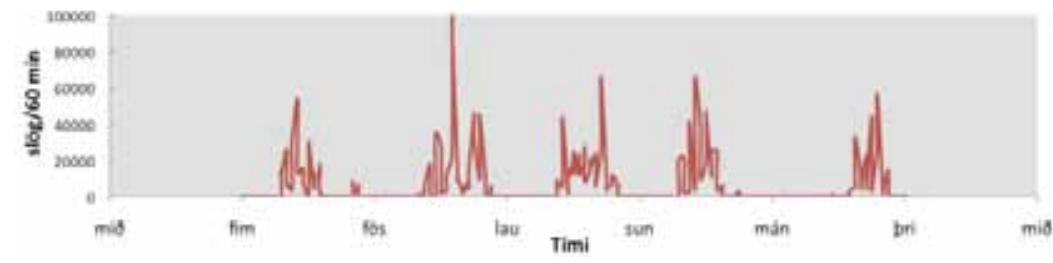

Mynd 1a. Dæmi um niðurstöður 9 ára barns sem hreyfði sig að jafnaði mikið hvern dag.

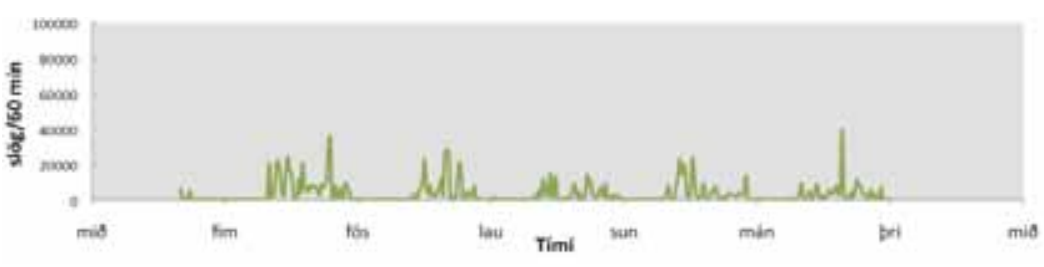

Mynd 1b. Dæmi um niðurstöður 9 ára barns sem hreyfði sig að jafnaði lítið.

var notast við óparað t-próf á normaldreifðar breytur og meðaltöl og staðalfrávik peirra birt. Mann-Whitney-Wilcoxon-próf var notað á ónormaldreifðar breytur og miðgildi og fjórðungsfrávik birt. Welch t-próf var notað pegar breytileiki milli kynja eftir aldri var ekki sá sami. Til að kanna hvort hugsanleg bjögun hefði átt sér stað við val á peim hópi sem undirgekkst hreyfimælingar, voru líkamspyngdarstuðlar pess hóps og pátttakenda sem ekki tóku pátt í hreyfimælingum bornir saman innan aldurs og kyns. Hvergi reyndist tölfræðilega marktækur munur á hópunum.

Fjölprepa aðhvarfsgreiningu (e. hierarchical linear modeling) var beitt til að útskýra breytileikann í fjölda mínútna á dag af meðalerfiðri og erfiðri hreyfingu (háða breytan). Sú breyta var umreiknuð á kvaðratrótarkvarða til að ná fram normaldreifingu. Óháða breytan pykkt húðfellinga var miðjuð til að fá fram augljósari túlkun á fjölprepa aðhvarfsgreiningarstuðlunum. Мeð fjölprepa aðhvarfsgreiningu mátti taka til greina lagskipta uppbyggingu gagnanna og pá fylgni sem getur leynst innan undirhópa eða klasa pess konar uppbyggingar. Til dæmis eru börn í sama skóla oftar en ekki líkari í ýmsum samanburði en börn sem borin væru saman milli skóla. Með pví að nota "skóla" sem slembiáhrif náði lokalíkanið að taka til greina og leiðrétta fylgni milli einstaklinga innan skólanna, sem oftar en ekki má rekja til sameiginlegra pátta í umhverfi og atferli samrýmdra hópa. Með pví að reikna innanflokkafylgni (e. intraclass correlation) var hægt að segja til um hve stóran hluta heildarbreytileika háðu breytunnar var að finna milli skóla. Við mat á mátun peirra líkana sem voru prófuð var stuðst við Bayesian Information Criteria (BIC). Eina óháða breytan sem athuguð var utan kyns, aldurs, húðpykktar og búsetu, og ekki tengdist háðu 
Tafla II. Leiðrétt meðaltöl fyrir hreyfingu (mínútur) af miðlungserfiðri ákefð hreyfingar samkvæmt besta mati fjölprepa að̌hvarfsgreiningarlíkans par sem sést samanburður á kynjum eftir aldri og búsetu. Reiknað var með meðalhúðpykkt fyrir bæði kyn samkvæmt töflu I.

\begin{tabular}{lccc}
\hline & & $\begin{array}{c}9 \text { ára } \\
\text { Meðaltal (mín) }\end{array}$ & $\begin{array}{c}15 \text { ára }^{\ddagger} \\
\text { Meðaltal (mín) }\end{array}$ \\
\hline $\begin{array}{l}\text { Meðaltalslengd hreyfingar af } \\
\text { miðlungserfiðri og erfiðri ákefð } \\
\text { meðal stelpna }\end{array}$ & Borg $^{\dagger}$ & 24,4 & 30,1 \\
\cline { 2 - 4 } & Bær & 19,5 & 24,7 \\
\hline $\begin{array}{l}\text { Meðaltalslengd hreyfingar af } \\
\text { miðlungserfiðri og erfiðri ákefð } \\
\text { meðal stráka* }\end{array}$ & Sveit & 17,0 & 20,9 \\
\cline { 2 - 4 } & Borg & 34,8 & 40,4 \\
\hline
\end{tabular}

* strákar hreyfðu sig marktækt meira en stelpur $(p<0,0001)$

† börn í borg hreyfðu sig marktækt meira en börn í bæjum og sveitum $(p<0,03)$

$\ddagger 15$ ára hreyfðu sig marktækt lengur á bessari ákefð samanborið við 9 ára börn $(p=0,006)$

breytunni var félagshagfræðilegur bakgrunnur barnanna (mæld sem flokkabreyta - lágur, mið, hár - út frá tekjum foreldra). Tölfræðiforritið $\mathrm{R}$ (version 2.11.1, www.r-project.org/) var notað við úrvinnslu gagna pessarar rannsóknar og nlme aðgerðapakkinn við greiningu fjölprepalíkansins.

\section{Niðurstöður}

Lýsandi upplýsingar um úrtak rannsóknarinnar með tilliti til holdafars og hreyfibreyta eru settar fram í töflu I. Par er einnig að finna tölfræðilegan samanburð á pessum breytum milli kynja. Niðurstöður fjölprepa aðhvarfsgreiningar leiddu í ljós að hreyfing yfir 3400 slög/mín tengdist kyni pannig að strákar hreyfðu sig lengur af pessari ákefð $(\mathrm{p}<0,0001)$, eldri börn hreyfðu sig lengur af pessari ákefð $(\mathrm{p}=0,006)$, aukin húðpykkt var tengd minni hreyfingu af pessari ákefð $(p=0,001)$ og að börn á Reykjavíkursvæðinu hreyfðu sig lengur af pessari ákefð samanborið við börn î

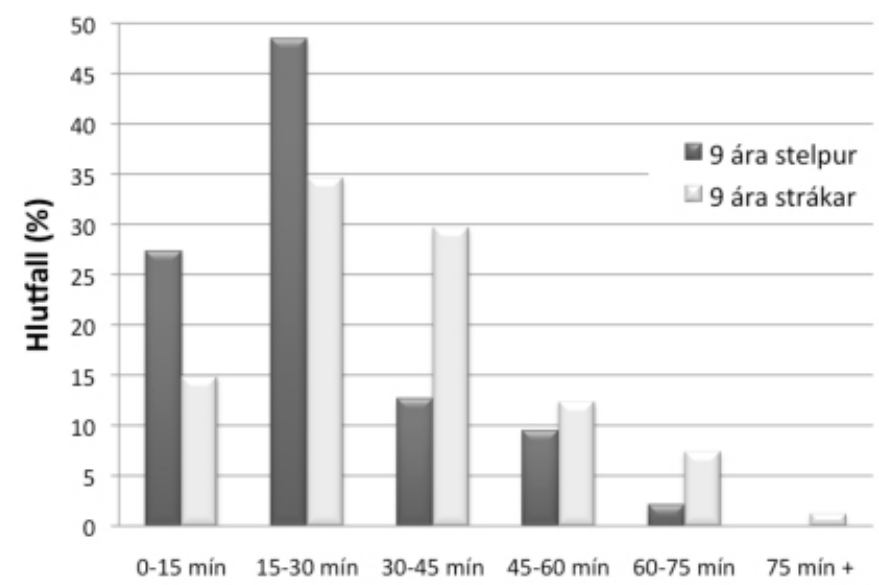

Mynd 2. Meðallengd daglegrar hreyfingar af miðlungserfiðri ákefð (>3400 slög/mín) meðal 1769 ára barna. bæjum $(\mathrm{p}=0,03)$ og strjálbýli á Norðausturlandi ( $\mathrm{p}=0,006)$. Breytileikinn í meðaltalsfjölda mínútna yfir 3400 slög/mín hvern dag var mun minni milli skóla en innan skóla. Innanflokkafylgni er hlutfall heildarbreytileikans í gildum fjölda mínútna yfir 3400 slögum/mín milli skóla og reiknaðist $24 \%$, pannig að lág fylgni var á milli gilda breytunnar innan hvers skóla. Um $46 \%$ útskýranlegs breytileika í meðaltalsfjölda mín yfir 3400 slög/mín/dag milli skóla (stig 2) útskýrðist af pví á hvaða svæði skólarnir voru (höfuðborgarsvæði, Norðausturland - péttbýli, Norðausturland - dreifbýli). Breyturnar aldur, kyn og pykkt húðfellinga útskýrðu aftur á móti mun lægra hlutfall útskýranlegs breytileika hreyfingar innan skóla (stig 1), eða rúm 6\%. Leiðrétt meðaltöl samkvæmt fjölprepa aðhvarfslíkani fyrir lengd hreyfingar af meðalerfiðri og erfiðri ákefð innan hvers hóps barna er að finna í töflu II par sem sjá má að almennt eyddu 15 ára börn fleiri mínútum á dag í hreyfingu af pessari ákefð samanborið við 9 ára börn. Flest 9 ára börn sem og 15 ára stúlkur hreyfðu sig í 15-30 mínútur á dag af meðalerfiðri og erfiðri ákefð í (myndir 2 og 3) meðan algengast var að 15 ára drengir hreyfðu sig að jafnaði í 30-45 mínútur á dag af pessari ákefð (mynd 3). Samkvæmt viðmiðum um meðalerfiða og erfiða hreyfingu uppfylltu um 5\% 9 ára barna ráðleggingar Lýðheilsustöðvar, eða $2 \%$ stúlkna og 8,5\% 9 ára stráka. Hlutfall 15 ára unglinga er ekki nema um $9 \%$ að meðaltali, eða 1,5\% stúlkna og 14,5\% drengja sem uppfylltu pessar sömu ráðleggingar (mynd 4).

\section{Umræða}

Lágt hlutfall 9 og 15 ára barna hreyfði sig í samræmi við ráðleggingar Lýðheilsustöðvar samkvæmt hlutlægum mælingum með hröðunarmælum. Strákar hreyfðu sig að jafnaði meira en stelpur og hver lota meðalerfiðrar og erfiðrar hreyfingar var ein til tvær mínútur að jafnaði. Níu ára strákar hreyfðu sig meira en peir 15 ára, sé litið til hreyfingarinnar út frá slögum/ mínútu, en ekki var tölfræðilega marktækur munur á meðalerfiðri og erfiðri hreyfingu peirra. Svipaða sögu er að segja um samanburð stelpna. Samkvæmt fjölprepa aðhvarfsgreiningu tengdist aukin hreyfing af meðalerfiðri og erfiðri ákefð minni pykkt húðfellinga, pví að vera strákur, vera 15 ára og búa á höfuðborgarsvæðinu frekar en í bæ eða sveit.

Almenn staða hreyfingar meðal barna og unglinga hvað varðar ákefð og tímalengd er um margt óljós vegna peirra mismunandi hröðunarmælaviðmiða sem í umferð eru. ${ }^{15-17}$ Sú eining 
sem oftast er notuð til að áætla orkunotkun við hreyfingu er MET (e. metabolic equivalent), en 1 MET jafngildir peirri orku sem líkaminn eyðir í algerri hvíld, sem aftur jafngildir grunnbrennslu (e. resting metabolic rate - RMR) fullorðins einstaklings í hvíld (1 MET = 3,5 $\left.\mathrm{mlO}_{2} / \mathrm{kg} / \mathrm{mín}\right)$. Hreyfing fullorðinna sem eykur efnaskipti líkamans prefalt til sexfalt umfram grunnbrennsluna (3-6 MET) hefur verið skilgreind sem meðalerfið hreyfing, en hreyfing yfir 6 MET sem erfið hreyfing. ${ }^{2}$ Ef ákefð hreyfingar samkvæmt MET er skilgreind fyrir börn verður að taka tillit til pess að grunnbrennsla peirra sem hlutfall af líkamspyngd er almennt nokkru hærri en fullorðinna. Sýnt hefur verið fram á að grunnbrennslan minnkar úr $6 \mathrm{ml} / \mathrm{kg} /$ mín við fimm ára aldur niður í 3,5 $\mathrm{ml} / \mathrm{kg} / \mathrm{mín}$ við 18 ára aldur. ${ }^{22}$ Preföld grunnbrennsla barna er pví hærri en 10,5 ml/kg/mín (3 MET) og ákefð hreyfingar sem samsvarar slíkri orkueyðslu yrði ofmetin. Allmargar rannsóknir hafa engu að síður birt niðurstöður um hlutfall barna sem hreyfa sig samkvæmt hreyfiráðleggingum, en taka framangreint ekki til greina. ${ }^{19,23,24}$

Rösk ganga barna á aldrinum 6-16 ára hefur verið mæld og skilgreind á bilinu 4,6-6,4 km/klst en á slíkum hraða slógu hröðunarmælarnir um og yfir $3000 \mathrm{slög/mín} \mathrm{og} \mathrm{orkueyðsla} \mathrm{barnanna} \mathrm{var}$ um og yfir 4 MET sé miðað við grunnbrennslu fullorðinna. ${ }^{16,17}$ Séu 3 MET hins vegar notuð til viðmiðunar og spájöfnu ${ }^{24}$ beitt, kemur í ljós að neðri mörk meðalerfiðrar hreyfingar 9 ára barna eigi að vera um 1000 slög/mín. Pví hafa verið færð fyrir pví rök ${ }^{15}$ að algeng viðmið24 séu of lág og valdi rangri flokkun hreyfingar út frá ákefð hennar.

Niðurstöður erlendra rannsókna sem tekið hafa til greina viðmiðin um að mörkin skuli ekki sett neðar en við 3000 slög/mín, séu ActiGraph $^{\mathrm{TM}}$ hröðunarmælarnir notaðir, eru hreint ekki uppörvandi, en pó mjög í anda peirra niðurstaðna sem birtar eru hér. Viðamikil bresk rannsókn ( $\mathrm{n}=5595)$ sýndi fram á að einungis 2,5\% 11 ára barna hreyfðu sig í 60 mínútur eða meira af meðalerfiðri og erfiðri ákefð dag hvern (skilgreind sem $\geq 3600$ slög/mín). ${ }^{12}$ Niðurstöður bandarísku NHANES 2003-2004 og 2005-2006 rannsóknarinnar á úrtaki $(\mathrm{n}=2498)$ á aldrinum 8-17 ára sýndu ennfremur að 7,6\% barna uppfylltu ráðleggingar um 60 mínútur á dag af meðalerfiðri og erfiðri hreyfingu (skilgreind sem $\geq 3000$ slög/ mín). ${ }^{25}$ Miðað við stöðu of pyngdar og offitu meðal evrópskra og bandarískra barna ${ }^{26}$ má kannski segja að pessar niðurstöður komi ekki algerlega á óvart.

Hreyfimynstur yngri barnanna í pessari rannsókn var að vissu leyti frábrugðið pví sem

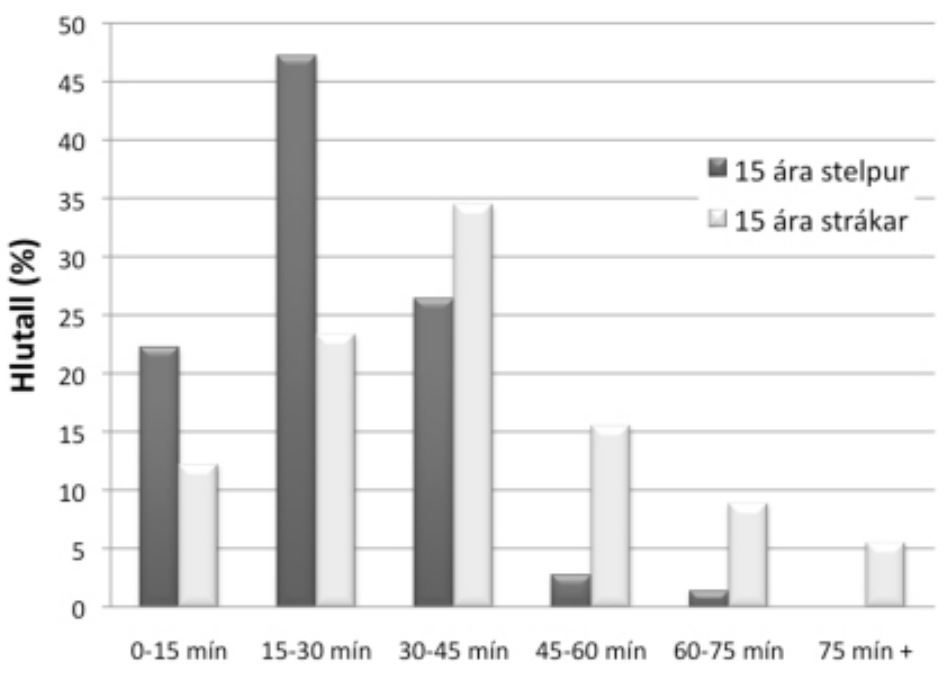

Mynd 3. Meðallengd daglegrar hreyfingar af miðlungserfiðri ákefð (>3400 slög/mín) meðal 16215 ára barna.

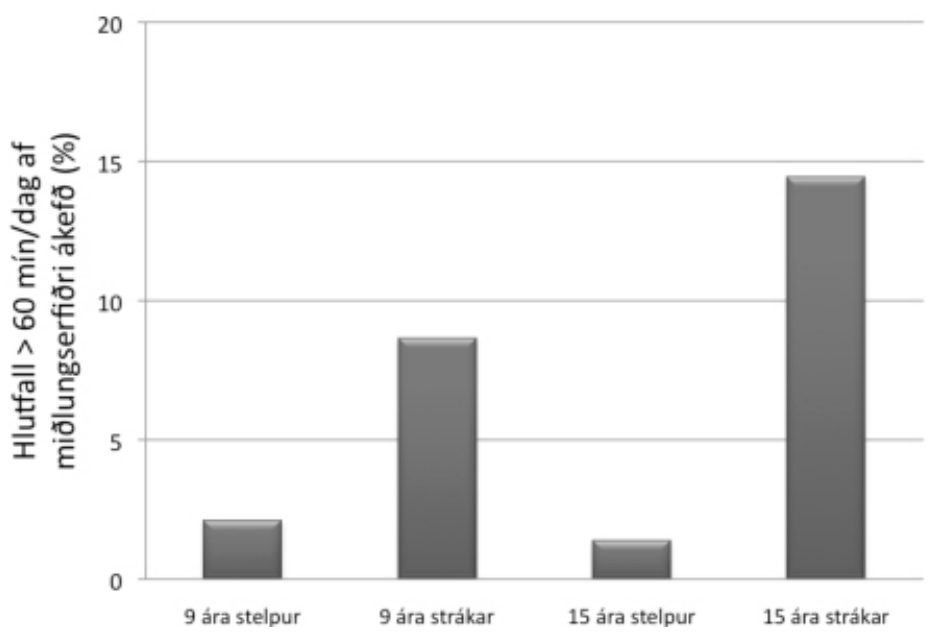

mældist hjá peim eldri pví hreyfilotur peirra yfir viðmiðunarmörkum meðalerfiðrar hreyfingar vöruðu að meðaltali skemur, en voru aftur á móti fleiri. Ennfremur má lesa út úr gögnunum, ef litið er til hreyfingarinnar út frá miðgildisslögum á mínútu, að yngri börnin hreyfðu sig almennt meira. Раð er að segja, pau yngri voru líklega meira á léttri hreyfingu en eldri pátttakendurnir. Pessar niðurstöður koma heim og saman við ályktanir sem dregnar hafa verið af öðrum niðurstöðum rannsókna á hreyfimynstri barna. ${ }^{27}$

Rannsóknin styður niðurstöður fjölda erlendra rannsókna á hreyfingu hvað varðar muninn á meðalerfiðri og erfiðri hreyfingu milli kynja.7 Bent hefur verið á að par sem rannsóknir frá mismunandi löndum með mismunandi félagslegt, menningarlegt, veðurfarslegt og náttúru-
Mynd 4. Hlutfall

pátttakenda yfir ráðlögðum viðmiðum Lýðheilsustöðvar um miðlungserfiða og erfiða hreyfingu hoern dag vikunnar. 
legt umhverfi sýni að strákar hreyfi sig meira en stelpur, megi álykta að pað stafi ekki síður af líffræðilegum páttum en umhverfislegum. ${ }^{19}$ Ennfremur hefur verið bent á að muninn milli kynjanna megi hugsanlega útskýra með mun minni erfiðri hreyfingu meðal stelpna, sem aftur ítrekar mikilvægi hreyfiíhlutunar sem sérstaklega tekur pað til greina. ${ }^{24}$

Niðurstöður sýndu ennfremur að peir pátttakendur sem voru með meiri fitu undir húð, hreyfðu sig minna af meðalerfiðri og erfiðri ákefð samanborið við jafnaldra sem ekki höfðu jafn pykkar húðfellingar. Erlendar rannsóknir hafa leitt í ljós svipuð tengsl hreyfingar og líkamsfitu sem aftur ýtir undir mikilvægi pess að börn fái nægjanlega mikla hreyfingu dag hvern til að fyrirbyggja ofpyngd. ${ }^{28}$

Tengsl búsetu og hreyfingar barna hafa lítið verið rannsökuð með hlutlægum mælingum og eru um margt misvísandi. Pó hafa rannsóknir frá Bandaríkjunum sýnt að börn sem búa í strjálbýli eru líkleg til pess að eyða minni tíma í hreyfingu af meðalerfiðri og erfiðri ákefð pótt pað samband geti einnig farið eftir aldri. ${ }^{29}$ Útskýringar á ástæðum tengsla milli búsetu og fjölda mínútna af meðalerfiðri og erfiðri ákefð innan okkar úrtaks gætu allt eins verið veðurfarslegar. Meirihluti barnanna af höfuðborgarsvæðinu var mældur í upphafi hausts pegar veður var betra en til að mynda pegar börn á Akureyri voru mæld síðla hausts og farið var að snjóa. Tengsl árstíma og veðurs við mælingar á hreyfingu hafa verið rannsökuð og benda niðurstöður til pess að börn á skólaaldri hreyfi sig að jafnaði meira á sumrin en veturna, eða sem nemur um og yfir 100 slög/ mín. ${ }^{12,30}$

Styrkur rannsóknarinnar er margvíslegur. Fyrst skal telja pá nýju pekkingu á stöðu hreyfingar meðal 9 og 15 ára barna sem nú birtist í fyrsta sinn. Pátttökuhlutfall í rannsókninni var ágætt og valið var af handahófi úr úrtakinu hverjir yrðu mældir með hröðunarmælum. Ekki var munur á líkamspyngdarstuðli peirra sem völdust í hreyfimælinguna og peirra sem tóku ekki pátt í henni. Hlutlægar mælingar voru gerðar á hreyfingu pátttakenda sem hugsanlega gefur réttmætari mynd af stöðu mála en niðurstöður spurningakannana.

Vert er að minnast á nokkra takmarkandi pætti mælinganna. Hröðunarmælarnir nema einungis hreyfingu í einu plani, sem pýðir að peir greina ekki mun á erfiðleikastigi við göngu á flatlendi, upp stiga eða til dæmis við hjólreiðar og róður. Peir greina ekki heldur pungaberandi hreyfingu eins og lyftingu lóða og pess háttar. Mælirinn er ekki vatnsheldur og pví fellur til að mynda öll hreyfing í sundlaugum utan útreikninga á áætlaðri hreyfingu pátttakendanna.

\section{Ályktanir}

Niðurstöður pessarar rannsóknar benda til pess að alltof lágt hlutfall 9 og 15 ára barna hreyfi sig nægjanlega lengi af meðalerfiðri og erfiðri ákefð dag hvern. Eins og í öðrum rannsóknum fundust neikvæð tengsl milli hreyfingar og holdafars 9 og 15 ára íslenskra barna. Einnig virðast drengir almennt hreyfa sig meira en stúlkur, og á pað sérstaklega við um meðalerfiða og erfiða hreyfingu. Pessar niðurstöður benda til pess að íhlutana sé pörf til pess að auka meðalerfiða og erfiða hreyfingu barna á skólaaldri.

\section{Pakkir}

Rannsóknarteymið stendur í pakkarskuld við alla pá fjölmörgu pátttakendur rannsóknarinnar Lífsstíll 9 og 15 ára Íslendinga sem gáfu tíma sinn, polinmæði og prek í págu verkefnisins. Eins á allt starfsfólk skólanna 18 sem lagði sig fram um að útvega okkur góða aðstöðu og svigrúm til mælinga pakkir skildar. Einnig pakkar rannsóknarteymið fyrir styrkveitingar frá Rannís, Íprótta- og Ólympíusambandi Íslands (ÍSÍ), Rannsóknasjóðum Kennaraháskóla Íslands og Háskóla Íslands, menntamálaráðuneytinu og öllum peim sem lögðu hönd á plóginn við framkvæmd rannsóknarinnar.

\section{Heimildir}

1. Warburton DE, Nicol CW, Bredin SS. Health benefits of physical activity: the evidence. CMAJ 2006; 174: 801-9.

2. World Health Organization. Physical activity and health in Europe: evidence for action. WHO Regional Office for Europe, Kaupmannahöfn 2006.

3. Lee IM, Buchner DM. The importance of walking to public health. Med Sci Sports Exerc 2008; 40(7 Suppl): S512-8.

4. Johannsson E, Arngrimsson SA, Thorsdottir I, Sveinsson T. Tracking of overweight from early childhood to adolescence in cohorts born 1988 and 1994: overweight in a high birth weight population. Int J Obes (Lond) 2006; 30: 1265-71.

5. Jónsson SH, Héðinsdóttir M. Líkamspyngd barna á höfuðborgarsvæðinu - er hlutfall barna yfir kjörpyngd hætt að aukast? Lýðheilsustöð og heilsugæsla höfuðborgarsvæðisins, Reykjavík 2010.

6. Chinapaw MJ, Mokkink LB, van Poppel MN, van Mechelen W, Terwee CB. Physical activity questionnaires for youth: a systematic review of measurement properties. Sports Med 2010; 40: 539-63.

7. Dencker M, Andersen LB. Health-related aspects of objectively measured daily physical activity in children. Clin Physiol Funct Imaging 2008; 28: 133-44.

8. Murphy SL. Review of physical activity measurement using accelerometers in older adults: considerations for research design and conduct. Prev Med 2009; 48: 108-14.

9. Ekelund U, Sjostrom M, Yngve A, et al. Physical activity assessed by activity monitor and doubly labeled water in children. Med Sci Sports Exerc 2001; 33: 275-81.

10. Trost SG, Ward DS, Moorehead SM, Watson PD, Riner W, Burke JR. Validity of the computer science and applications (CSA) activity monitor in children. Med Sci Sports Exerc 1998; 30: 629-33. 
11. Guinhouya $\mathrm{CB}$, Hubert $\mathrm{H}$, Soubrier S, Vilhelm C, Lemdan M, Durocher A. Moderate-to-vigorous physical activity among children: discrepancies in accelerometry-based cutoff points. Obesity (Silver Spring) 2006; 14: 774-7.

12. Riddoch CJ, Mattocks C, Deere K, et al. Objective measurement of levels and patterns of physical activity. Arch Dis Child 2007; 92: 963-9.

13. Dencker M, Thorsson O, Karlsson MK, et al. Daily physical activity in Swedish children aged 8-11 years. Scand J Med Sci Sports 2006; 16: 252-7.

14. Faghópur Lýðheilsustöðvar um ráðleggingar um hreyfingu. Ráðleggingar um hreyfingu. Bæklingur. Lýðheilsustöo, Reykjavík 2008.

15. Guinhouya CB, Lemdani M, Vilhelm C, Durocher A, Hubert $\mathrm{H}$. Actigraph-defined moderate-to-vigorous physical activity cut-off points among children: statistical and biobehavioural relevance. Acta Paediatr 2009; 9: 708-14

16. Treuth MS, Schmitz K, Catellier DJ, et al. Defining accelerometer thresholds for activity intensities in adolescent girls. Med Sci Sports Exerc 2004; 36: 1259-66.

17. Puyau MR, Adolph AL, Vohra FA, Butte NF. Validation and calibration of physical activity monitors in children. Obes Res 2002; 10: 150-7.

18. Magnusson KT, Sveinsson T, Arngrimsson SA, Johannsson E. Predictors of fatness and physical fitness in nine-year-old Icelandic school children. Int J Pediatr Obes 2008; 3: 217-25.

19. Riddoch CJ, Bo Andersen L, Wedderkopp N, et al. Physical activity levels and patterns of 9- and 15-yr-old European children. Med Sci Sports Exerc 2004; 36: 86-92.

20. Cole TJ, Bellizzi MC, Flegal KM, Dietz WH. Establishing a standard definition for child overweight and obesity worldwide: international survey. BMJ 2000; 320: 1240-3.
21. Mattocks C, Leary S, Ness A, et al. Calibration of an accelerometer during free-living activities in children. Int $\mathrm{J}$ Pediatr Obes 2007; 2: 218-26.

22. Schofield WN. Predicting basal metabolic rate, new standards and review of previous work. Hum Nutr Clin Nutr 1985; 39 Suppl 1: 5-41.

23. Nader PR, Bradley RH, Houts RM, McRitchie SL, O’Brien M. Moderate-to-vigorous physical activity from ages 9 to 15 years. JAMA 2008; 30: 295-305

24. Trost SG, Pate RR, Sallis JF, et al. Age and gender differences in objectively measured physical activity in youth. Med Sci Sports Exerc 2002; 34: 350-5.

25. Mark AE, Janssen I. Influence of bouts of physical activity on overweight in youth. Am J Prev Med 2009; 36: 416-21.

26. Internationl Obesity Task Force Childhood obesity report. 2009; www.iotf.org/childhoodobesity.asp 23. nóvember 2009

27. Welk GJ, Corbin CB, Dale D. Measurement issues in the assessment of physical activity in children. Res Q Exerc Sport 2000; 71(2 Suppl): S59-73.

28. Fulton JE, Dai S, Steffen LM, Grunbaum JA, Shah SM, Labarthe DR. Physical activity, energy intake, sedentary behavior, and adiposity in youth. Am J Prev Med 2009; 37(1 Suppl): S40-9.

29. Powell KE, Roberts AM, Ross JG, Phillips MA, Ujamaa DA, Zhou M. Low physical fitness among fifth- and seventhgrade students, Georgia, 2006. Am J Prev Med 2009; 36: 30410

30. Kolle E, Steene-Johannessen J, Andersen LB, Anderssen SA. Seasonal variation in objectively assessed physical activity among children and adolescents in Norway: a cross-sectional study. Int J Behav Nutr Phys Act 2009; 6: 36.

\section{Physical activity of 9 and 15 year old Icelandic children - Public health objectives and relations of physical activity to gender, age, anthropometry and area of living}

Objective: The main objective of the study was to assess to what degree nine and fifteen year old Icelandic children followed the national physical activity (PA) guidelines for children set forth by the Icelandic Public Health Institute, which recommend no less than 60 minutes of moderateto-vigorous physical activity a day (MVPA).

Material and methods: The study was conducted between September 2003 and January 2004 at eighteen randomly selected schools in the capital area of Reykjavik and towns and rural areas in the northeast. All nine years old $(\mathrm{N}=662)$ and fifteen years old $(\mathrm{N}=661)$ students were offered to participate. Half of the children were randomly chosen to partake in the PA part of the study where 176 nine-year-old and 162 fifteen-year-old children yielded usable data. We measured participants' height, weight and skinfold thickness and their PA by ActiGraph ${ }^{\mathrm{TM}}$ with respect to moderate-to-vigorous intensity (defined as counts $>3400 \mathrm{cpm}$ ) and average volume.

Results: Only $5 \%$ of 9 -year-old and $9 \%$ of 15 year-old students followed the recommended PA guidelines of at least 60 minutes a day of MVPA. MVPA was positively associated with sex (being a boy) and age, but negatively associated with skinfold thickness. Those living in the capital area of Reykjavik rather than in smaller towns and rural areas were likelier to accrue more minutes of MVPA per day.

Conclusion: The results highlight the importance of developing PA interventions targeting children of school age. It is important to research and evaluate different ways as to how these interventions should best be conducted.

Magnusson K, Arngrimsson SA, Sveinsson Th, Johannsson E.

Physical activity of $\mathbf{9}$ and 15 year old Icelandic children - Public health objectives and relations of physical activity to gender,

age, anthropometry and area of living. Icel Med J 2011; 97: 75-81

Key words: physical activity, children, body composition, accelerometers.

Correspondence: Kristján Pór Magnússon, ktm@hi.is 